\title{
クライオジェニック高分子材料 ーカルド型高分子一
}

\author{
田中皓・徳 満 勝 久
}

\begin{abstract}
クライオジェニック材料は， LNG の輸送・貼蔵，リニアモーターカー，超伝導磁気共鳴 装置，光化学ホールバーニング超高密度メモリー，宇宙開発など，21 世紀における高度 な最新技術が関与する分野において不可欠な先端材料である。いままで使用されてきた金 属・無機材料を，重量，断熱性，加工性，腐食性，などで優れた性質を有する高分子材料 で置き換えることが待望されている。
\end{abstract}

\section{1.はじめに}

クライオジェニック温度域 (cryogenic temperatures) とは，一般に約 $120 \mathrm{~K}$ 以下の温度領域を指す。この温度域 での使用に耐える材料を “クライオジェニック材料”之称 することにする。クライオジェニック材料は，21 世紀にお ける高度な最新技術の確立に不可欠な先端材料である。す なわち，エネルギー（LNG の輸送・貯蔵・ハンドリング), 交通 (リニアモーターカー), 医療 (超伝導磁気共鳴装置), 情報 (光化学ホールバーニング超高密度メモリー), 宇宙開 発（ロケット）などさまざまな分野においてその使用が見 込まれる。

これまで，金属・無機材料がクライオジェニック材料と して実用上多く使用され, その長い研究実績に基づいて重 要な位置を占めている。しかし，これらの金属・無機材料 には, 重量, 断熱性, 加工性, 腐食性, コストなど, 改良 を要する面が多々ある。このため, 従来の金属・無機材料 にはない優れた性能をもつ, クライオジェニック高分子材 料に対する期待・要望が高まっている。

しかし, 既存の高分子材料は, クライオジェニック温度 域でぜい性破壊，熱収縮の大きいことが問題となる。高分 子材料の低温ぜい性を改善すること，すなわち，クライオ ジェニック高分子材料の創製は 21 世紀の夢のひとつであ る。

このような状況下にあって, 高分子材料の熱伝導性, 機 械的特性をクライオジェニック温度域で測定した研究例が
いくつか報告・紹介されている11 5)。また，クライオジェ ニック材料として高分子複合材料を利用する試み ${ }^{6) ~ 10), ~ す ~}$ なわち，高分子材料に，金属・ガラス繊維・高強度繊維 (炭素繊維, 液晶性高分子) を複合し,クライオジェニック 材料としての最適化を図ろうとする試みあ報告されてい る。

\section{2. 低温ぜい性改善へのひとつの提案}

低温においても高分子の分子運動 (分子全体, あるいは, 局所部分の運動) が凍結されずに熱運動できるような高分 子材料を見いだすことができれば，低温下で外部から印加 された力学的エネルギーを高分子の分子運動によって吸収 できる可能性がある。すなわち, 高分子材料の低温ぜい性 改善への期待が広がる。

このような観点に立ち，低温であ結合角を変えることの できる構造を主鎖骨格中に導入することを考えた。ここで いう結合角を変えることのできる構造5)には, 酸素や硫黄 なごの非共有電子対を有する原子, 複素環構造, さらには, カルド構造などがある。

われわれは, カルド構造をむつ高分子を選んだ。それは, 側鎖（フルオレン環）が適当にかさ高く, 適当にリジッド な構造であり, クライオジェニック温度域で分散を示すで あろうと考えたからである。

“クライオジェニック温度で優れた性質を賦与するため には高分子材料にどのような構造（高次構造をむ含めて）
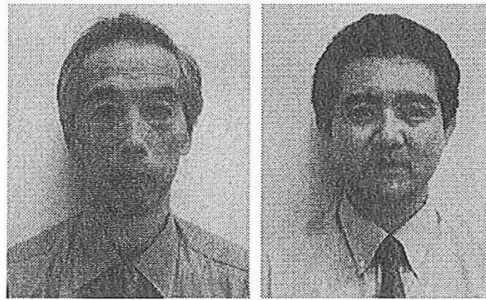

TANAKA, Akira （写真左）滋賀県立大学工学部材料科学科（522-8533 彦根市八坂町 2500)・教授, Ph.D. 1967年京都大学工学部高分子化学科修士課程修了, 1970年マサチュー セッッ大学大学院博士課程修了. 専門は高分子物性〈趣味〉テニス, コントラクトブリッジ TOKUMITSU, Katsuhisa (写真右) 滋賀県立大学工学部材料科学科（522-8533 彦根市八坂 町 2500)・講師, 博士 (工学)。1988年 京都大学工学部高分子化学科修士課程修了，2001年 まで大阪ガス(株)勤務．専門は高分子物性〈趣味〉テニス，スキー 
を導入すればよいのか”という問を解決する目的で平成 10 平成 12 年度に NEDO のプロジェクト，「クライオ ジニック新規高分子材料の創製研究」の研究を行った。 本稿では, NEDOの研究結果 (エステル系カルドポリ マー), および，その後にわれわれが行った研究結果（ウレ タン系カルドポリマー）を併せて, カルド型高分子の化学 構造が分子運動性に与える影響，ひいては，低温ぜい性に 与える影響について展望してみる。

\section{3. カルド型高分子について}

\section{1 カルド型高分子とは}

オックスフォードの辞典にはカルドの意味として, hinge (蝶番) とある。また, Korshak らの総説11)では, ラテン語から発した loop (ループ) の意味に対応すると述 ベられている。別の表現をすれば，カルド型ポリマーとは 環状の基が高分子主鎖に直接結合した構造をむつポリマー の総称ということになる (図 1 参照)。

\section{2 カルド型ポリマーの一般的な特徵}

カルド型ポリマーは, その構造を反映して，すなわち， 主鎖に直角にかさ高い置換基が存在することにより，ポリ マー主鎖の回転束縛, 主鎖および側鎖のコンホメーション 規制などが発現される。このため, カルド構造が結合角の 変化を容易にし，低温での分子運動を維持する。それに よって，低温でのぜい性低下を抑制し，耐低温性を示すと いう物性上の特徴が発現するものと期待される。

カルド型高分子である [poly(BPEF-CHDA)] の曲げ強度 は, 参考デー夕 (一例 $)^{12)}$ ではあるが, $100 〜 200 \mathrm{~K}$ の温度 範囲で, テフロン（既存の有機材料の中で低温材料として 優れた材料の部類に属する）のそれよりも高い值を示し， 低温材料としての potential が伺える (図 2 参照)。

他方，カルド型ポリマーは，芳香族性の高いことから， 高い熱安定性と高い屈折率 $(1.62 \sim 1.63)$ を示す。また，力 ルド型ポリマーは, 環状の基が，高分子主鎖に対して直交 して結合した構造をあつため, 低い複屈折率13) (ポリカー ボネートの 1/2 以下) を示し，オプトエレクトロニクス材 料としても優れた物性を発現寸ることが知られている。さ

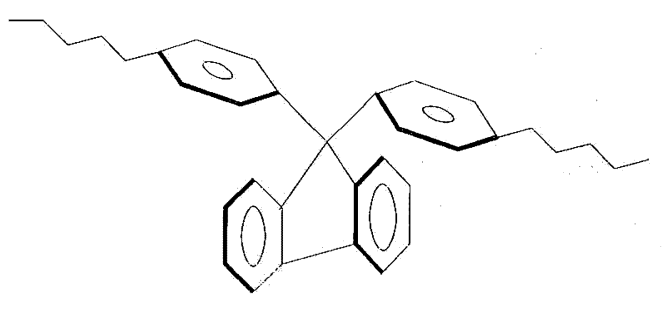

$$
\text { Cardo }=\text { Loop }
$$

図 1 カルドポリマー
らには，カルド型ポリイミド膜が，ループ状のかさ高い化 学構造に由来する高い気体透過性をむつという報告 ${ }^{14)}$ なされている。

\section{4. カルド型高分子の化学構造と分子運動性}

\section{1 カルド型ポリマーの動的粘弾性スペクトルの概要}

読者の理解を容易にするために，冒頭で（本章で）カル ド型ポリマーの動的粘弾性スペクトルの概要について記述 する。この概要は, これまで行ってきた種々のカルド型ポ

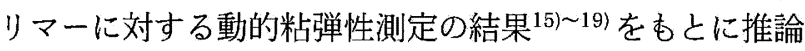
したあのである。

勳的秥戦性スへクトルに観測されるカルド型ポリマーの 分散は, 主として, 4 個に分類される。それらの分散を, 高 温部より $\alpha, \beta_{2}, \beta_{1}, \gamma$ と名づける。以下に各分散の帰属(図 3 参照)・特徵について述べる。

(1) $\alpha$ 分散： $\alpha$ 分散は主鎖のセグメント運動に帰属され る。すなわち，ガラス転移に対応する。その温度位置は力 ルド構造, カルド構造を結ぶユニットの化学構造, カルド 構造の含有率に強い影響を受ける。すなわち， $\alpha$ 分散温度 は主鎖のフレキシビリティーによって支配される。

(2) $\beta_{2}$ 分散はサブセグメントの運動に帰属される。サブ セグメントとは, 図 3 に示されるように, セグメント内の 一部分であり，セグメントの運動性と密接に関係する構成 単位である。つまり, $\beta_{2}$ 分散の温度位置は $\alpha$ 分散温度と連

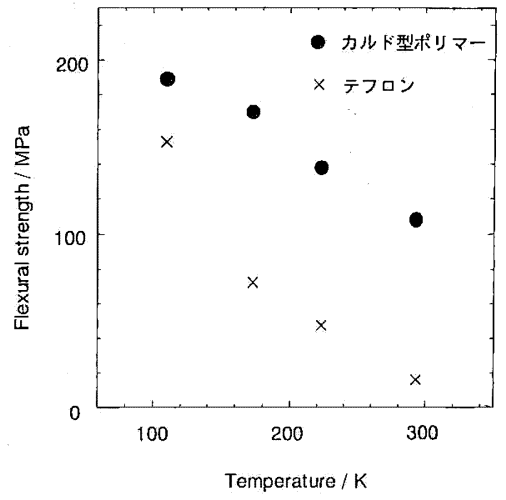

図 2 カルド型ポリマーとテフロンとの曲げ強度の比較の一 例

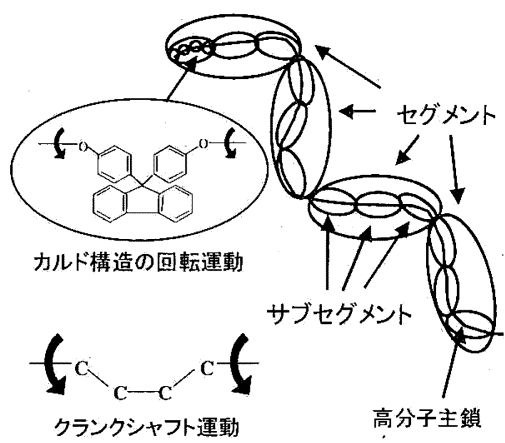

図 3 カルド型ポリマーの分子運動 
動している。それゆえ, $\beta_{2}$ 分散温度位置もまた, カルド構 造を結ぶユニットの化学構造, カルド構造の含有率と強い 相関を示す。

(3) $\beta_{1}$ 分散は, 図 3 に示されるように, BPEF 部分（力 ルド構造を含む）の回転運動に帰属される。 $\beta_{1}$ 分散温度位 置は, カルド構造を結ぶユニットの化学構造, カルド構造 の含有率にほとんよ゙影響を受けない。

(4) $\gamma$ 分散は非常に小さいサイトの運動で，たとえば，$\mathrm{O}-\left(\mathrm{CH}_{2} \mathrm{CH}_{2}\right)-\mathrm{O}-,-\mathrm{CH}_{2}-\left(\mathrm{CH}_{2} \mathrm{CH}_{2}\right)-\mathrm{CH}_{2}-$, などのクランク シャフト運動や小さな側鎖の運動が対応する。したがっ て, その分散の発現は, カルド構造, 含有カルド量には直 接には関係しない。これには，分散温度位置の異なる少な くとあ 2 個の分散が存在すると思われるが, 現在のとこ ろ, 特定するには至っていない。

\section{2 カルド型ポリマーと非カルド型ポリマーの動的粘弾 性スペクトル}

カルド構造（フルオレン環）の有無が動的粘弾性スペク トル, すなわち, 分子運動性に与える影響について調べた。 エステル結合型ポリマーの場合には, フルオレン環を有す る試料として poly(BPEF-CHDA)を, フルオレン環を含有 しない試料として poly(BPEP-CHDA)を用いた。また，ウ レタン結合型ポリマーの場合には，フルオレン環を有する 試料として poly(BPEF-MDI)を, フルオレン環を含有しな い試料として poly(BPEP-MDI)を用いた。

エステル結合型ポリマーの結果を図 4 に示す。図 4 より 明らかなように, フルオンン環を有するカルド型ポリマー (BPEF 系) のガラス転移温度 ( $\alpha$ 分散温度) は, フルオレ ン環を有しない非カルド型ポリマー（BPEP系）よりも, $90 \mathrm{~K}$ 程度高いことがわかる。図示はしないが, ウレタン結
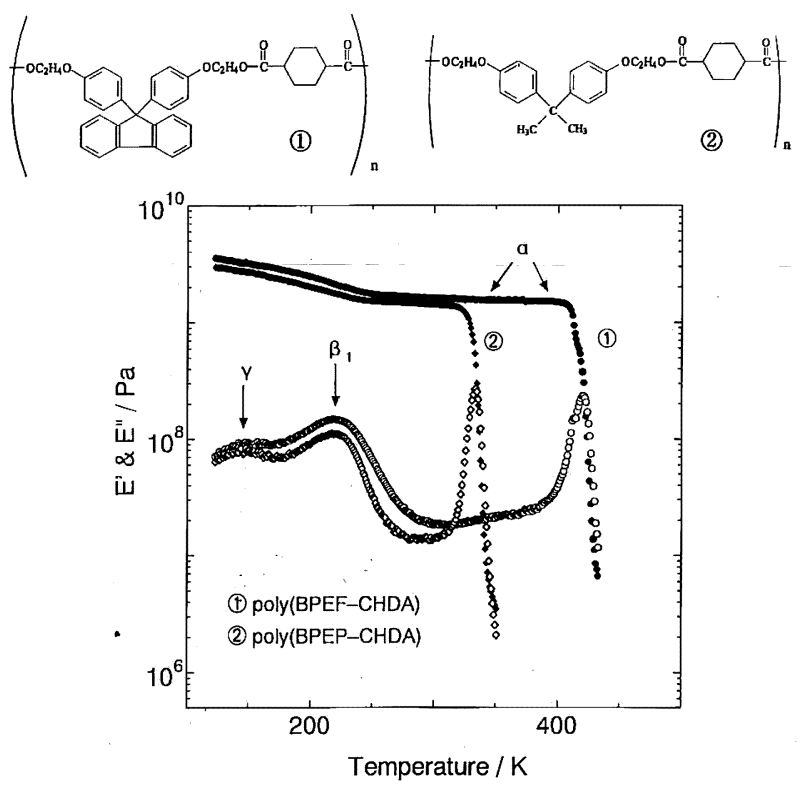

図 4 Poly(BPEF-CHDA) と poly(BPEP-CHDA)の動的弾性 率および動的損失の温度依存性曲線
合型ポリマーに扔いてもカルド型ポリマーの $\alpha$ 分散温度 は非カルド型ポリマーのそれよりも高く，その差は $50 \mathrm{~K}$ 程度であった。

一方, カルド型ポリマー中の BPEF の回転運動あるいは BPEP の回転運動に帰属される $\beta_{1}$ 分散の温度位置は, 力 ルド，非カルドによらず同じである。これは BPEF と BPEP の運動がほぼ同じェネルギーで起こること示唆す る。

$\gamma$ 分散の温度位置も, また, カルド, 非カルドによらず, ほぼ同じである。この事実は，エトキシル基中に含まれる $\mathrm{C}_{2} \mathrm{H}_{4}$ の回転運動も, またカルド構造の有無によって影響 を受けないことを示唆する。

液体窒素温度 $(77 \mathrm{~K})$ での伸張試験における破壊伸びに, カルド型ポリマーと非カルド型ポリマーとの間で有意な差 異が認められた。すなわち，前者のそれが約 $11 \%$ であっ たのに対し，後者のそれは約 $6 \%$ であった ${ }^{12)}$ このように, 変形が大きくなるとカルド構造の有無の影響が現れること は注目に值する。分子運動とは直接には関係のない別の因 子がぜい性破壊を少なからず支配していることが伺える。

\section{3 カルド型構造を結ぶユニットの化学構造の分子運動 性に与える影響}

カルドポリマーの各結合ユニットの化学構造の違いが分 子運動性に与える影響について述べる。用いたポリマーの 化学構造をまとめて図 5 に示す。また, 各々のカルドポリ マーにおける, 各分散の温度位置を表 1 にまとめて示す。 表より明らかなように， $\alpha$ 分散温度 (ガラス転移温度) は カルド構造を結ぶユニットの化学構造によって大きく変化 することがわかる。 poly(BPEF-TDI) の $\alpha$ 分散温度があっ とあ高い。TDI ユニットが, 用いた試料中では, 高分子鎖

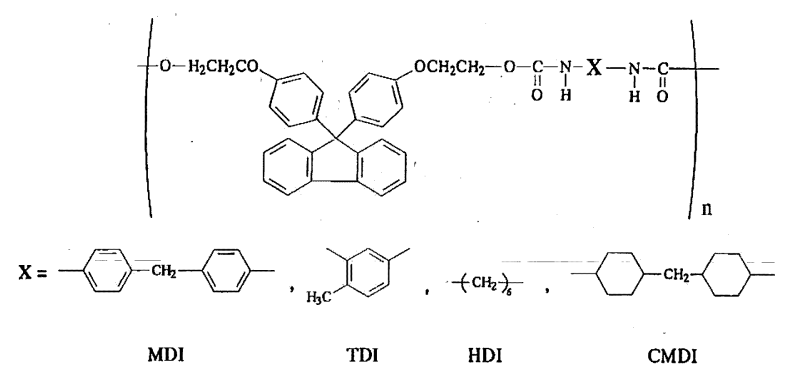

図 5 種々のウレタン系カルド型ポリマーの化学構造

表 1 Poly(BPEF-MDI), Poly(BPEF-TDI), Poly(BPEF-HDI), Poly (BPEF-CMDI), おょび Poly (BPEF-CHDA)の力 学分散の温度位置 $\left(T_{\max } / \mathrm{K}\right)$

\begin{tabular}{lcccc}
\hline \multicolumn{1}{c}{ Sample } & \multicolumn{1}{c}{$T_{\max } \alpha(\mathrm{K})$} & $T_{\max } \beta_{2}(\mathrm{~K})$ & $T_{\max } \beta_{1}(\mathrm{~K})$ & $T_{\max } \gamma(\mathrm{K})$ \\
\hline Poly(BPEF-MDI) & 425 & 337 & 192 & - \\
Poly(BPEF-TDI) & 448 & 290 & 197 & - \\
Poly(BPEF-HDI) & 334 & 303 & 200 & - \\
Poly(BPEF-CMDI) & 413 & 346 & 194 & - \\
\hline Poly(BPEF-CHDA) & 421 & - & 219 & 148 \\
\hline
\end{tabular}


に剛直性を付与する効果があっとも高いことがわかる。

$\beta_{2}$ 分散はウレタン系にのみ観測される。また，その温度 位置も結合ユニットの影響を受ける。最大の $\alpha$ 分散温度を 示したもっとあ剛直な poly(BPEF-TDI)が，あっとも低い $\beta_{2}$ 分散温度を与えることは興味深い。この事実は, $\beta_{2}$ 分散 の分子運動性は主鎖自身の剛直性よりも，結合ュニットの かさ高さが強く影響することを示唆する。

$\beta_{1}$ 分散はすべてのカルド型ポリマーにおいて観測され， その温度位置は結合ユニットの影響を受けない傾向があ る。この分散は誘電緩和測定によって BPEF 構造の回転運 動であることが推定された ${ }^{20)}$ 。本実験に用いた試料には, BPEF 構造が共通して含まれていることからあ， $\beta_{1}$ 分散は カルド型ポリマー中における BPEF 構造の運動に起因す ることが支持される。

あっと屯低温域に観測される $\gamma$ 分散は，エステル系カル ドポリマーに拉いては大きな分散として観測されるが，ウ レタン系カルドポリマーにおいてはその存在は判別しにく い。分散温度域が $150 \mathrm{~K}$ という非常に低温であることを 考えると， $\gamma$ 分散は，たとえば，エトキシル基における $\mathrm{C}_{2} \mathrm{H}_{4}$ の回転運動，クランクシャフト運動のような小さな エネルギーで生じる，きわめて小さな単位の運動であろう と考えられるが, 現在のところ, 特定されるには至ってい ない。

\section{4 カルド構造含有率の分子運動性に与える影響}

カルド構造含有率を变化させるために, 試料として (BPEF-MDI) と (PPG-MDI) との共重合体を用いた。すな わち, poly[(BPEF-MDI $)_{n}$-co-(PPG-MDI $\left.)_{m}\right]$ の組成比 $(m / n$ : $1 / 7,1 / 3,3 / 5,1 / 1,5 / 3,3 / 1)$ の異なる試料を用いた。その 化学構造を図 6 に，動的粘弾性の測定結果を図 7 に示す。 また， $\alpha, \beta_{2}, \beta_{1}, \gamma$ 分散のピーク温度位置の組成比依存性 を図 8 に示す。得られた結果をまとめると次のようになろ 亏。

(I) ガラス転移 ( $\alpha$ 分散) 温度は, カルド構造含有率の減 少とともに低下する。

(II) $\beta_{2}$ 分散温度も同様にカルド構造含有率の減少ととも に低温側にシフトし，その緩和強度も低下する傾向があ る。とくに, BPEF 含有率がモル質量で約 $30 \%(m: n=3$ : 5) 以下の場合, $\beta_{2}$ 分散は観測されにくくなる。これは, 主 鎖中に含まれる剛直なカルド構造割合の低下に伴い, 主鎖

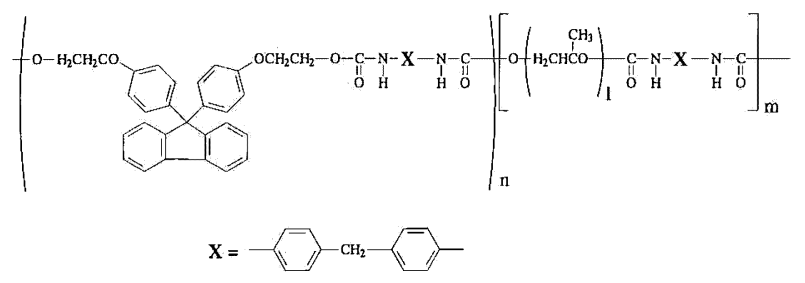

図 6 Poly[(BPEF-MDI $\left.)_{n}-c o-(\mathrm{PPG}-\mathrm{MDI})_{m}\right]$ の化学構造

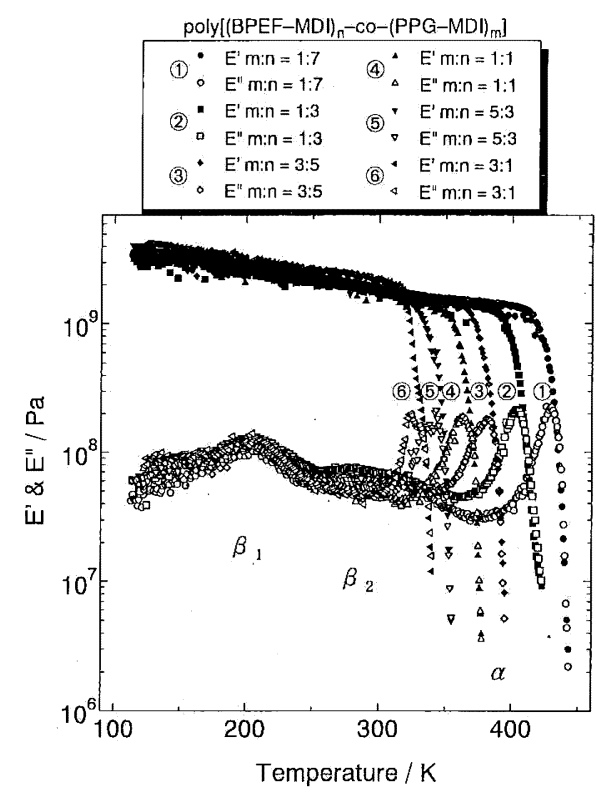

図 7 Poly[(BPEF-MDI $)_{n}$-co-(PPG-MDI $\left.)_{m}\right]$ の粘弾性スペクト ル

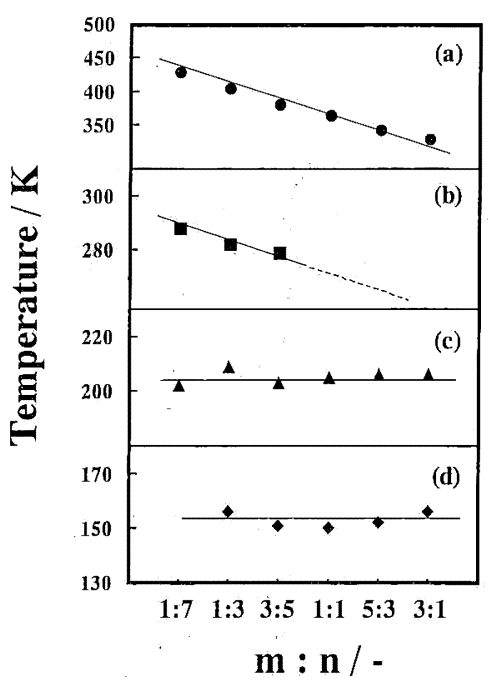

図 8 Poly[(BPEF-MDI $\left.)_{n}-c o-(\mathrm{PPG}-\mathrm{MDI})_{m}\right]$ の力学的分散の温 度位置
(a) $\alpha$ 分散,
(b) $\beta_{2}$ 分散,
(c) $\beta_{1}$ 分散, および (d) $\delta$ 分 散.

のセグメント運動に起因する $\alpha$ 分散温度と, サブセグメン 下の分子運動に起因する $\beta_{2}$ 分散温度がきわめて接近した 結果であると思われる。

(III) $\beta_{1}$ 分散温度は，すべての試料において，ほぼ同じ温 度域で観測されるが，その分散領域に掞ける緩和エネル ギーはカルド構造の減少とともに若干低下する傾向がある ことがわかった。

(IV) $\gamma$ 分散は，本測定に用いたウレタン系カルド型ポリ マーではほとんど観測されなかった。先のエステル系カル ド型ポリマーの結果と併せて考えると, ウレタン系より比 較的柔軟なエステル系により結合されたエトキシル基中の $\mathrm{C}_{2} \mathrm{H}_{4}$ 回転運動が本分散温度において観測されるものと思 われる。 
しかしながら，ウレタン系カルドポリマーでも， BPEF 部分を結ぶポリオールの化学構造が变わると, たとえば, -O- $\left(\mathrm{CH}_{2} \mathrm{CH}_{2}\right)-\mathrm{O}$-の $\left(\mathrm{CH}_{2} \mathrm{CH}_{2}\right)$ を $\left(\mathrm{C}_{4} \mathrm{H}_{8}\right)$ になると, $\gamma$ 分散 の分散強度は大きくなる ${ }^{21,22) 。 ~}$

\section{5. 残された問題}

本稿に执いて, カルド型ポリマーの化学構造が分子運動 性に与える影響に関して，大まかではあるが，その傾向を 見いだすことができたと思う。しかしながら，ここで扱わ れたカルド型ポリマーの化学構造は, ごく一部で, 限られ ている。化学構造を変えたさらなる試みが必要であろう。 その中には, 先にあ述べたように, ポリオールの化学構造 を変えること,フルオレン環を別の環構造にすること，な どがあろう。

高分子の分子量む大きな影響を与えるのではないかと思 われる。カルド型ポリマーは, 高分子量化することがきわ めて困難であり, 得られたポリマーはせいぜい 10 万で あった。低温ぜい性と分子量の関係を検討することあ残さ れた問題のひとつである。

ここで調査した分子運動性は, 微少ひずみ（線形粘弾性 を示す）に対して得られたあのである。ひずみが高い（非 線形粘弾性を示す）場合の変形についての調査が必要であ る。ひとつの試みとして，われわれは，大きな変形に対し て非調和項（弹性の非線形性）の導入を提案している ${ }^{23) 。 ~}$

材料の変形様式 (圧縮変形・引張変形など) が低温ぜい 性破壊に与える影響についてあ調查する必要がある。これ には, 高次構造をはじめ, 高分子が本来もつ特徵である異 方性などが関与するのかむしれない。われわれは, 現在, 動的粘弾性実験を圧縮変形・引張变形の両モードで行って いる22)。また, 超音波（縦波・横波）による検討も計画して いる。

とああれ,クライオジェニック高分子材料の開発には, まだまだ，残された問題が多い。いま，その入り口にさし
かかったにすぎない。本稿が問題解决の糸口になれば幸い である。

\section{文献}

1) 一色節也: 高分子, 26, 563 (1977)

2) 矢野興紀：和田八三久, 高分子, 30,705 (1981)

3）和田八三久：高分子, 34, 32 (1985)

4) 矢野嘓紀, 山岡仁史：高分子, 39, 596 (1990)

5) 山岡仁史：高分子, 42, 262 (1993)

6) T. Aoki, T. Ishikawa, H. Kumazawa, Y. Morino: Adv. Compos. Mater., 10(4), 349 (2001)

7) E. F. Kharchenko, G. A. Mokeeva: MICC 90 (Moscow International Composites Conference), 1991, pp. 389

8) Y. Iwasaki, S.Nishijima, J. Yasuda, T. Hirooka, T. Okada: Adv. Cryogenic Eng. (Mater.), 36, 969 (1990)

9) Y. Iwasaki, J. Yasuda, T. Hirooka, K. Noma, S. Nishijima, T. Okada: Cryogenics, 31, 261 (1991)

10) D. Evans, J. T. Morgan: Cryogenics, 31, 220 (1991)

11) V. V. Korshak, S. V. Vinogradova, and Y.S. Vygodskii: J. Macromol. Chem.-Rev. Macromol. Chem. (C), 11(1), 45 (1974)

12）山田昌宏, 角本輝充, 矢野興紀, 田中 皓, 山岡仁史：工業材 料, 48, 11, $93(2000)$

13) B. Li, L. A. Prexta, Z. Shen, S. Z. D. Cheng, F. W. Harris: Polym. Prepr., 41(1), 105 (2000)

14) 竹村康彦：高分子, 49, 834 (2000)

15) A. Tanaka, M. Yamada, M. Yamada, C. Yamaguchi, K. Nitta, H. Nakatani: Repts. Progr. Polym. Phys. Jpn., 41, 429 (1998)

16) A. Tanaka, Y. Kozono, K. Nakano, M. Yamada, C. Yamaguchi: Repts. Progr. Polym. Phys. Jpn., 42, 305 (1999)

17）小園雄治：修士論文（滋賀県立大学）, 2001

18) Y. Kozono, A. Tanaka, M. Yamada, C. Yamaguchi: Polym. Prepr., Jpn., 49(10), 2885 (2000)

19) K. Tokumitsu, A. Tanaka, K. Kobori, M. Kitamura, Y. Kozono, M. Yamada: ACS PMSE Prepr., 87, 263 (2002)

20) O. Yano: private communication (2000)

21) K. Kobori, A. Tanaka, K. Tokumitsu, Y. Kozono, M. Yamada, K. Nitta: Polym. Prepr., Jpn., 50(12), 3088 (2001)

22) K. Kobori, K. Tokumitsu, A. Tanaka, M. Yamada, K. Nitta: Polym. Prepr., Jpn., 51(4), 802 (2002)

23) A. Tanaka, Y. Kozono, M. Shiga, M. Yamada, C. Yamaguchi: Polym. Prepr., Jpn., 50(4), 693 (2001) 